\title{
Maria DOLECKA
}

\section{POZYCJA JĘZYKA ANGIELSKIEGO \\ W ŚWIECIE}

W roku 1780 John Adams, drugi prezydent Stanów Zjednoczonych przedstawił w wystąpieniu przed Kongresem Akademii Amerykańskiej następującą wizję rozwoju języka angielskiego w przyszłości: "Język angielski jest predestynowany do tego, aby $w$ następnym, a także $w$ dalszych stuleciach stać się językiem światowym $w$ jeszcze bardziej powszechny sposób, aniżeli była nim łacina w przeszłości, czy obecnie język francuski. Przyczyna ku temu jest oczywista, ponieważ rosnqca liczba ludności Ameryki oraz jej uniwersalne powiqzania $i$ kontakty ze wszystkimi narodami przy wsparciu wptywu Anglii w świecie, dużego czy małego, wymuszq powszechne używanie tego języka..."1. Słowa wypowiedziane przed ponad dwustu laty stały się niezaprzeczalnym faktem. Obecne rozpowszechnienie i dominacja języka angielskiego $\mathrm{w}$ świecie jest fenomenem niespotykanym $\mathrm{w}$ historii rasy ludzkiej i jej języków, a także nieporównywalnym $z$ rolą i zasięgiem języków zajmujących czołową pozycję w przeszłości.

Wspomniana wyżej łacina była językiem panującym $w$ średniowieczu, ale tylko na obszarze Europy. Dominowała w sferze ówczesnej dyplomacji, w kancelariach władców i arystokratów, w twórczości literackiej, a także w filozofii i teologii oraz liturgii kościoła rzymsko-katolickiego. Członkowie średniowiecznych społeczności komunikowali się jednak na co dzień w swoich językach ojczystych, a wielu z nich, zwłaszcza tych, którzy pochodzili z niższych warstw społecznych, w ogóle języka łacińskiego nie znało. Łacina i język narodowy, jak chociażby polski, funkcjonowały w państwach ówczesnej Europy

1 Tłumaczenie własne. Cytat za: D. Crystal, English as a global language, Cambridge 1997, s. 66. 
niezależnie od siebie, występując w odmiennych sferach życia ${ }^{2}$. Także posługiwanie się językiem francuskim, który w okresie swojej dominacji wywarł olbrzymi wpływ na większość języków europejskich, nie miało charakteru masowego. Choć u szczytu swej popularności francuszczyzna zdobyła wielu zwolenników, przedostając się do literatury, nauki i życia towarzyskiego, nie zmienia to faktu, że była ona w zasadzie językiem funkcjonującym niemal wyłącznie $\mathrm{w}$ środowisku arystokracji, bogatej szlachty i zamożnego mieszczaństwa ${ }^{3}$.

We współczesnym świecie język angielski jest używany przez szerokie masy społeczne. Wielu ludzi musi komunikować się w tym języku, aby móc wykonywać swój zawód lub realizować hobby. Astronautyka, transport morski i lotniczy, prawie wszystkie międzynarodowe organizacje, wiele firm mających powiązania międzynarodowe, znaczna część nauki, świat muzyki i międzynarodowa kultura młodzieżowa uczyniły z niego swój język roboczy. Angielski stał się dzisiaj językiem, "nad którym słońce nigdy nie zachodzi"4, ponieważ jest reprezentowany na wszystkich kontynentach i wyspach trzech największych oceanów: na Atlantyku (Wyspa Św. Heleny), Oceanie Indyjskim (Seszele) i Pacyfiku (m.in. Hawaje).

Niemało trudności przysparza oszacowanie liczby użytkowników języka angielskiego. Można tu spotkać skrajne opinie i dane liczbowe, np. Stephan Matthews uważa, że język angielski z 350 mln użytkowników zajmuje drugie miejsce w świecie po języku chińskim $(1000 \mathrm{mln})^{5}$. Frank Palmer pisze natomiast, że „...jest to przypuszczalnie język $z$ największq liczbq rodzimych użytkowników (ludzi, dla których jest on pierwszym językiem) - jakkolwiek ten szacunek zależy od tego, czy potraktujemy chiński jako język jednolity; jeśli tego nie uczynimy, angielski stanie się dru-

2 Por. B. Nowowiejski, O stosunku do zapożyczeń z języków obcych w świetle historii języka polskiego, w: Z problematyki kształcenia językowego w szkole, red. P. Wróblewski, t. I, Białystok 1995, s. 13-14.

3 B. Nowowiejski, op. cit., s. 31 .

4 D. Crystal, op. cit., s. 67.

5 Liczba ta obejmuje przypuszczalnie tylko tzw. „native speakers”, czyli rodzimych użytkowników tego języka. Atlas języków. Pochodzenie i rozwój języków świata, red. B. Comrie, S. Matthews, M. Polinsky, Poznań 1998, s. 19. 
gim" $^{\prime \prime}$. W celu przedstawienia jak najbardziej wiernego obrazu rzeczywistości niektórzy językoznawcy ${ }^{7}$ zajmujący się tym zagadnieniem dzielą wszystkich użytkowników języka angielskiego na trzy grupy, którym nadają co prawda nieco odmienne nazwy, jednak ich modele nie różnią się między sobą. Grupy te składają się z:

- narodów ENL (English as a Native Language), dla których angielski jest językiem ojczystym (T. McArthur) lub L1 (Language 1) językiem pierwszym (D. Crystal);

- narodów ESL (English as a Second Language), wśród których funkcjonuje jako język drugi mający specjalny status;

- narodów EFL (English as a Foreign Language), czyli używających lub uczących się go jako języka obcego.

Do pierwszej grupy należą użytkownicy takich państw, jak: Stany Zjednoczone, Wielka Brytania, Irlandia, Kanada, Australia i Nowa Zelandia. Druga grupa obejmuje ponad 50 terytoriów, w większości byłych kolonii Wielkiej Brytanii, w których język angielski, często na równi z językiem danego regionu, ma status języka urzędowego bądź jest używany jako uniwersalne medium komunikacji międzynarodowej. W grupie tej znajdują się np.: Indie, Pakistan, Bangladesz, Kamerun, Ghana, Republika Południowej Afryki, Jamajka, Filipiny, Singapur, Tanzania. Trzecia, stale rozrastająca się grupa, obejmuje ponad 100 państw, w których angielski ma szczególne preferencje jako język obcy. W samych tylko Chinach języka angielskiego uczy się $10 \%$ ludności, co stanowi aż $100 \mathrm{mln}$. Według danych z $1995 \mathrm{r}$. grupa pierwsza liczy $337 \mathrm{mln}$, natomiast grupa druga 235 mln użytkowników. Najtrudniej jest oszacować liczbę posługujących się językiem angielskim jako obcym. Przy założeniu, że opanowanie języka angielskiego $\mathrm{w}$ grupie trzeciej jest na poziome (lub bliskie) znajomości języka rodzimych użytkowników, liczba

6 Język chiński mający 11 odmiennych wariantów jest zunifikowany wspólnym systemem graficznym, co umożliwia odczytanie dowolnego tekstu przez wszystkich użytkowników języka, jednak $\mathrm{z}$ tak dużą różnicą wymowy (porównywalną np. ze skalą odmienności fonetycznej między językiem francuskim i angielskim w rodzinie indoeuropejskiej), że zaburza ona komunikację między nimi. Zob. F. Palmer, Language and languages, w: The English Language, red. W. F. Bolton, D. Crystal, Penguin Books 1993, s. 3.

7 Taki podział przedstawiają: D. Crystal op. cit., s. 60-63 oraz T. McArthur w The English language or the English languages?, w: The English language, red. W. F. Bolton, D. Crystal, Penguin Books 1993, s. 324 . 
ta wyniosłaby $670 \mathrm{mln}$, natomiast stosując kryterium „umiarkowanej kompetencji" wzrosłaby ona aż do 1.8 mld osób. Obecnie najczęściej przyjmuje się rozwiązanie pośrednie, według którego liczba osób znających język angielski jako obcy wynosi od 1.2 do $1.5 \mathrm{mld}^{8}$, co oznacza, że jest ich znacznie więcej niż rodzimych użytkowników, którzy wraz z płynnie posługującymi się tym językiem stanowią blisko 1/4 ludności świata. Przy tak olbrzymiej rozpiętości terytorialnej oraz różnicach kultur nie dziwi fakt, że język angielski jest kalejdoskopem rozmaitych odmian. Braj B. Kachru i Larry E. Smith, wydawcy magazynu World Englishes już w samym tytule periodyku poprzez użycie liczby mnogiej podkreślają, że warianty te posiadają wysoki stopień autonomii ${ }^{9}$.

Obecny status światowy języka angielskiego jest między innymi rezultatem brytyjskiej polityki imperialnej, która "rozsiała” język angielski po całym świecie. W XVII i XVIII w. Wielka Brytania stała się czołową potęgą kolonialną. Wraz z ekspansją kolonialną, która osiąga punkt kulminacyjny pod koniec XIX $\mathrm{w}$. powstawały nowe połączenia morskie z metropolią, wzmacniały się struktury administracyjne podbitych państw, rozwijano wymianę handlową i zakładano misje chrześcijańskie. W XVIII w. rozpoczęto masowy handel niewolnikami i nabór siły roboczej do pracy na plantacjach, co spowodowało przemieszczanie ludności z Afryki i Azji w odległe zakątki świata. W takich warunkach zrodziła się potrzeba porozumienia się między różnojęzycznymi społecznościami, która doprowadziła do powstawania pidginów, czyli uproszczonych form języka, w których słownictwo (w tym wypadku języka angielskiego) stało się podstawą spontanicznie tworzącego się systemu komunikacji. Rozmowy kupców z Europy z ludnością tubylczą odbywały się często na statkach lub na nabrzeżu, stąd też pidginy handlowe charakteryzują się minimalnym zasobem słów i uproszczonymi strukturami gramatycznymi ${ }^{10}$. Słowo pidgin powstało właśnie w takich warunkach w XVII w. w portach południowych Chin, w których Anglicy i Chińczycy sprzedając swoje towary porozumiewali

\footnotetext{
8 Por. D. Crystal, op. cit., s. 53-61.

9 Por. T. McArthur, op. cit., s. 334.

10 Por. G. Smith i S. Matthews, Pidginy i języki kreolskie, w: Atlas języków. Pochodzenie i rozwój języków świata, Poznań 1998, s. 146-7.
} 
się w uproszczonym języku angielskim. Najczęściej przyjmowana etymologia objaśnia pidgin jako zniekształcenie angielskiego business w wymowie chińskiej. Pidgin chiński cechował niestabilny zasób słownictwa obejmujący zaledwie 700 wyrazów. W wypadku braku jakiegoś wyrazu zastępowano go konstrukcją opisową, w której wykorzystywano istniejące słownictwo ${ }^{11}$. Pidginy rodzą się $\mathrm{z}$ potrzeby kontaktu i tracą rację bytu, gdy konieczność porozumiewania się niknie. Pidgin chiński wymarł pod koniec XIX wieku, podobnie jak pidgin melanezyjski, pidgin z Japonii czy Wietnamu ${ }^{12}$.

Ogółem na podłożu języka angielskiego powstało 30 pidginów, z których większość została przejęta przez następne pokolenia, stając się językami kreolskimi ${ }^{13}$. Gdy pidgin zdobywa rodzimych użytkowników, zachodzą $\mathrm{w}$ nim zjawiska polegające na wzbogaceniu języka $\mathrm{w}$ nowe struktury słowotwórcze i składniowe, rozszerzeniu zasobu leksykalnego i poprawie systemu fonetycznego. Języki kreolskie są dzisiaj językami ojczystymi wielu społeczności, niektóre z nich uzyskały status języka państwowego np. bislama w Vanuatu lub tok pisin w Papui-Nowej Gwinei, pełniący funkcję języka urzędowego obok języka angielskiego i hiri-motu.

Na początku XIX w. Wielka Brytania wysunęła się na pierwsze miejsce $w$ świecie $w$ produkcji przemysłowej $i$ handlu. Większość innowacji z okresu rewolucji przemysłowej jest brytyjskiego pochodzenia. Takie nazwiska jak Thomas Newcomen, James Watt, Matthew Boulton, Richard Trevithick, George Sthephenson czy Michael Faraday odzwierciedlają osiągnięcia Wielkiej Brytanii w tym okresie. Postęp w nauce i przemyśle przyniósł nie tylko zmiany cywilizacyjne, lecz miał także olbrzymi wpływ na język. Pojawiła się nowa terminologia, słownik języka angielskiego wzbogacił się o dziesiątki tysięcy nowych haseł. Co więcej, korzystanie $\mathrm{z}$ dobrodziejstw nowych technologii i śledzenie myśli naukowej stało się możliwe tylko przy dobrej znajomości języka an-

11 Por. D. E. Zimmer, Neuanglodeutsch. Über die Pidginisierug der Sprache, w: Deutsch und anders die Sprache im Modernisierungsfieher, Reinbek bei Hamburg 1998, s. 73.

12 Tamże, s. 74.

13 Franc. créole, z portug. crioulo, "niewolnik”, który urodził się w domu swego pana; człowiek biały urodzony w państwie kolonialnym. Zob. Encyklopedia językoznawstwa ogólnego, red. K. Polański, Warszawa 1999, s. 339. 
gielskiego, co zrodziło u obcokrajowców konieczność nauki tego języka. Szczególnie po kampanii napoleońskiej (1792-1815) Wielka Brytania zaczęła zbierać plony swoich odkryć, przyjmując wysłanników z różnych państw i ucząc ich nowych metod produkcji przemysłowej ${ }^{14}$. Pod koniec XIX w. liczba ludności USA (100 mln) przerosła niejeden kraj Europy Zachodniej, a gospodarka Stanów Zjednoczonych była najbardziej produktywna i rozwijała się najszybciej w świecie. $\mathrm{W} X X \mathrm{w}$. światowa obecność języka angielskiego została podtrzymana i wzmocniona przez nowe amerykańskie supermocarstwo gospodarcze. Językiem, który stoi za dolarem, jest oczywiście angielski ${ }^{15}$.

„Ekonomiczna siła” języka, a właściwie wspólnoty językowej, obliczana jako produkt narodowy brutto wszystkich rodzimych użytkowników danego języka świadczy o roli danej społeczności, a także jej języka w sferze gospodarki na arenie ogólnoświatowej. Według badan z roku 1990, język angielski zajmuje pod tym względem zdecydowanie pierwsze miejsce. Wypracowywany przez kraje anglojęzyczne produkt narodowy brutto (4271 mld dolarów) osiąga znacznie wyższy poziom niż innych wspólnot językowych - w porównaniu z Japonią (1277) czy krajami niemieckojęzycznymi, które lokują się kolejno na drugim i trzecim miejscu, jest on aż ponad trzykrotnie wyższy ${ }^{16}$. "Język nie ma osobnej egzystencji, (...) niezależnej od ludzi, którzy nim mówiq. Język istnieje tylko $w$ umysłach $i$ ustach $i$ uszach $i$ rękach $i$ oczach ich użytkowników. Jeśli oni odnoszq sukces na arenie międzynarodowej, ich język odnosi także sukces" ${ }^{17}$.

Dynamiczny wzrost produkcji zmusił przedsiębiorstwa we wczesnych latach XX wieku do rywalizacji i walki o klientów, skutkiem czego było powstanie konkurencji, nierozłącznie związanej z reklamą i marketingiem. W 1972 r. na 30 czołowych agencji reklamowych w świecie zdecydowana większość (27) stanowiła własność USA, tylko jedna należała do Wielkiej Brytanii a dwie do Japonii. Język angielski pozostaje niezmiennie językiem oficjalnym międzynarodowych gremiów

14 Por. D. Crystal, op. cit., s. 72.

15 Tamże, s. 8.

16 Por. U. Ammon, Die deutsche Sprache: Lingua franca im Schatten von Englisch, "Deutschland" 12/94, s. 46.

17 D. Crystal, op. cit., s. 5. 
reklamowych takich, jak European Association of Advertasing Agencies, jego funkcja $w$ reklamie jest wyrazem wpływu na inne języki narodowe ${ }^{18}$.

Nieodłącznymi atrybutami języka angielskiego są dzisiaj takie jego określenia, jak: język światowy, współczesna lingua franca, język globalny czy międzynarodowy, podkreślające znaczenie angielskiego w komunikacji między różnymi narodami. Przejęciu funkcji uniwersalnego języka międzynarodowego przez język angielski sprzyjało niezwykłe ożywienie kontaktów międzynarodowych, gwałtowny rozwój komunikacji, wymiany handlowej i nauki $w$ wieku XX. Zbliżenie narodów nastąpiło zwłaszcza $w$ latach po II wojnie światowej. W tym czasie powstały takie organizacje międzynarodowe, jak: ONZ (1945), Bank Światowy (1945), UNESCO, UNICEF (1946), Światowa Organizacja Zdrowia (1948) i Międzynarodowa Agencja Energii Atomowej (1957). Nigdy dotąd nie spotykało się tak wiele państw (ponad $180 \mathrm{w}$ wypadku niektórych organów ONZ) w jednym miejscu ${ }^{19}$. Język angielski pełni $w$ wielu organizacjach funkcję języka oficjalnego, jak np. w ONZ obok języka francuskiego, hiszpańskiego, rosyjskiego, chińskiego i arabskiego ${ }^{20}$.

Współdziałanie wielu państw $\mathrm{w}$ ramach jednej organizacji byłoby bardzo kosztowne i utrudnione, gdyby komunikacja członków odbywała się poprzez tłumaczenia na ich języki ojczyste. Właśnie w takich sytuacjach jawi się potrzeba "wspólnego" języka. Sprawozdania o gospodarce finansowej międzynarodowych organizacji dają ogólne wyobrażenie o skali wydatków na tłumaczenia, np.: sporządzenie ok. 867 tys. rozmaitych dokumentów na ponad $773 \mathrm{mln}$ stron w 4 językach kosztowało ONZ w 1970 r. około 30 mln dolarów ${ }^{21}$. W Unii Europejskiej tłumaczenia pochłaniają $40 \%$ budżetu administracyjnego $^{22}$. Utrzymanie wielojęzyczności $w$ tej organizacji wiąże się nie

\footnotetext{
18 Por. D. Crystal, op. cit., s. 86-87.

19 Tamże, s. 10.

20 Por. Encyklopedia językoznawstwa ogólnego, op. cit., s. 275.

21 Za M. Susskinem, Paninterlingwa. Powszechny język międzynarodowy, Warszawa 1990, s. 56.

22 Por. F. Rötzer, Sprachliche Monokultur oder Sprachenvielfalt?, w: Telepolis. Magazin der Netzkultur, Hannover 1997, s. 4, www.heise.de.
} 
tylko z olbrzymimi wydatkami, lecz także przysparza wielu innych trudności, które powodują między innymi spowolnienie procedur politycznych. Planowane w niedalekiej przyszłości rozszerzenie Unii spowoduje wzrost liczby języków państw członkowskich z 11 do 22 . Już dzisiaj rozważa się, jakie rozwiązania należałoby wprowadzić, aby sprostać nowej sytuacji. Germanista Hans-Jürgen Krumm objaśnia: „Problem zaczyna się przy bardzo banalnej sprawie, ile kabin do tłumaczenia symultanicznego można umieścić $w$ jednym pomieszczeniu. Przy 22 językach byłoby mianowicie 462 możliwości tłumaczeń" ${ }^{23}$. Jedno z rozwiązań polegałoby na ustanowieniu języka angielskiego jako języka pośredniczącego w tłumaczeniach. W tym wypadku każdy tłumacz oprócz języka ojczystego musiałby posługiwać się doskonale językiem angielskim. Tłumaczenia nie byłyby dokonywane bezpośrednio, np. z języka francuskiego na niemiecki, lecz najpierw na angielski, z którego niemiecki native speaker tłumaczyłby dopiero na swój język ojczysty. Przy takim rozwiązaniu do obsługi spotkań wystarczyłoby 22 tłumaczy ${ }^{24}$. Integracja zmusza, przynajmniej do czasu wynalezienia perfekcyjnie działających automatycznych systemów translatorskich, do ustanowienia uniwersalnego medium komunikacji lub utworzenia hierarchii językowej. W wielonarodowych organizacjach różnorodność językowa jest redukowana do jak najmniejszej ilości języków oficjalnych, których liczba wynika najczęściej z wpływu politycznego i ekonomicznego członków (por. języki urzędowe ONZ). Funkcjonując jako lingua franca, język angielski pełni funkcję jedynego języka oficjalnego w wielu organizacjach naukowych (np. Balitic Marine Biologists, European Academy of Anasthesiology) i sportowych (np. African Hockey Federation, Asian Amateur Atletic Assiociation) ${ }^{25}$.

Język angielski stał się także medium komunikacji naukowej. Według badań z 1981 r., większość periodyków naukowych ukazuje się właśnie w tym języku: z dziedziny biologii i fizyki - 85\%, z medycyny $73 \%$, z matematyki $69 \%$, z chemii $67 \%$, a w naukach kompute-

\footnotetext{
23 Za H. Korn, Perfekt Englisch oder defekt mehrsprachig?, w: Der Standard, Wien, s. 1, www.detlev-mahnert.de/symposion.html.

24 Tamże, s. 1.

25 Por. D. Crystal, op. cit., s. 80.
} 
rowych ponad $90 \%^{26}$. W znacznym stopniu przyczyniły się do tego kraje anglojęzyczne poprzez duże nakłady na badania i dorobek w postępie naukowym. Udział samych tylko Stanów Zjednoczonych w finansowaniu przedsięwzięć naukowych stanowi $35 \%$ wydatków światowych. W USA mieszka 1/4 naukowców świata, tyle samo co we wszystkich krajach słabo rozwiniętych razem ${ }^{27}$. Także pochodzenie laureatów nagrody Nobla, zwłaszcza $\mathrm{w}$ dziedzinie nauk przyrodniczych jest wskaźnikiem przesunięcia przywództwa naukowego $\mathrm{w}$ świecie na to państwo. W roku 1910 procentowy udział naukowców z krajów niemieckojęzycznych $\mathrm{w}$ nagrodzie Nobla $\mathrm{w} w / \mathrm{w}$ dziedzinie przewyższał o ponad 3\% udział ich kolegów z krajów anglojęzycznych. Dzisiaj jest on około sześciokrotnie niższy wobec udziału naukowców z krajów anglojęzycznych, który wynosi blisko $64,1 \%{ }^{28}$.

Stany Zjednoczone były kolebką rewolucji elektronicznej w latach 70-tych XX wieku, która ostatecznie ugruntowała pozycję języka angielskiego. W pierwszych komputerowych systemach operacyjnych pojawiło się automatycznie słownictwo i składnia angielska. Przewodnictwo Ameryki w technologii komputerowej sprzyja szerzeniu się języka angielskiego, na którym bazują języki programowania, internet i terminologia dotycząca samego oprzyrządowania. Większość akronimów (np. www, http) da się rozszyfrować tylko przy pomocy języka angielskiego. Deficyty wielu języków we własnej terminologii zmuszają do używania angielskich pożyczek, wykazujących, zależnie od języka biorcy, różny stopień asymilacji. Na 100 terminów komputerowych wśród 10 wybranych języków europejskich najniższy stopien adaptacji występuje w języku duńskim (52\%) i niemieckim (57\%), gdzie większość terminologii funkcjonuje $\mathrm{w}$ postaci zapożyczeń właściwych bezpośrednich. Najwięcej zasymilowanych terminów występuje w fińskim $(93 \%)$, francuskim $(86 \%)$ i polskim $(82 \%)^{29}$.

\footnotetext{
26 D. Crystal, op. cit., s. 102.

27 Por. J. M. Tortosa, Polityka językowa a języki mniejszości: od Wieży Babel do Daru Języków, Warszawa 1986 , s. 79.

28 Por. U. Ammon, Die deutsche Sprache, op. cit., s. 47.

29 Por. D. E. Zimmer, Hundert Computerbegriffe in zehn europäischen Sprachen, w: Deutsch und anders - die Sprache im Modernisierungsfieber, Reinbek bei Hamburg 1998, s. 86-104.
} 
Rozwój technologii komputerowych przyczynił się do powstania internetu, który stał się motorem wzrostu komunikacji międzynarodowej. Jego zarodkowa forma arpanet (Advanced Research Projects Network) wykiełkowała w latach 60-tych w Ameryce i służyła początkowo celom militarnym. Po krótkim czasie do arpanetu podłączone zostały sieci placówek naukowych. W 1973 r. powstało pierwsze transkontynentalne połączenie z Wielką Brytanią i Norwegią. W 1982 r. został opracowany protokół transmisyjny TCP/IP, który umożliwił połączenie różnych sieci we właściwy internet. Na początku lat 90-tych internet przełamał swoje ograniczenie do kręgu ekspertów i rozprzestrzenił się eksplozyjnie na innych użytkowników ${ }^{30}$. W 1992 r. 60\% poczty elektronicznej powstawało $w$ krajach anglojęzycznych, z czego aż $40 \%$ pochodziło z USA. Około 80\% informacji elektronicznych w świecie ukazuje się $\mathrm{w}$ języku angielskim, który stał się prawdziwą lingua franca internetu ${ }^{31}$.

Dominacja języka angielskiego $\mathrm{w}$ takich sferach jak gospodarka, polityka i nauka wpływa na wszystkie inne aspekty życia społecznego, jak chociażby prasę, radio, kino i muzykę. W tych dziedzinach kraje anglojęzyczne od dawna utrzymują pozycję lidera. Język angielski jest przez blisko 400 lat ważnym medium w prasie. W 1994 r. 1/3 światowych gazet była publikowana w krajach ESL (English as a Second Language), $\mathrm{w}$ większości w języku angielskim. Jeszcze bardziej wymowne są dane dotyczące roli poszczególnych tytułów na arenie ogólnoświatowej. Według Book of Lists z 1997 r., do pierwszej piątki świata należą następujące gazety wydawane $w$ języku angielskim: The New York Times, The Washington Post, The Wall Street Journal, The Times i The Sunday ${ }^{32}$.

Angielski był pierwszym językiem transmitowanym przez radio (1906 r.). Zaledwie kilka lat później (w 1920 r.) powstała w Pittsburghu w Pensylwanii pierwsza komercyjna radiostacja. W $1996 \mathrm{r}$. The World Service radia $B B C$ nadawał audycje przez ponad 1000 godzin tygodniowo, dla $140 \mathrm{mln}$ słuchaczy na całym świecie, $\mathrm{z}$ tego około $1 / 3 \mathrm{w}$ języku

30 Por. U. Ammon, Das Internet und die internationale Stellung der deutschen Sprache, w: Deutsch global. Neue Medien - Herausforderungen für die Deutsche Sprache, Köln 2000, s. 242.

31 Por. D. Crystal, op. cit., s. 105-108.

32 Tamże, s. 83-84. 
angielskim. Także BBC English Radio emituje programy dwujęzyczne i anglojęzyczne przez 100 godz. tygodniowo. London Radio Services oferuje dziennie serwis wiadomości 10000 radiostacji w całym świecie ${ }^{33}$. Radio w znacznym stopniu przyczyniło się do popularyzacji różnych gatunków muzycznych wywodzących się z Ameryki, jak np. jazzu, bluesa, folku czy muzyki country. Właśnie w ten sposób, słuchając piosenek, wiele osób po raz pierwszy styka się z językiem angielskim. Muzyka w języku angielskim jest szczególnym fenomenem dwudziestego wieku wywierającym wpływ na nowoczesną kulturę popularną. W latach 60-tych wykonawcy muzyki pop dwóch anglojęzycznych narodów, czyli USA (Bill Haley i The Comets oraz Elvis Presley) i Wielkiej Brytanii (The Beathles i Rolling Stones), zrewolucjonizowali rynek muzyczny i stali się dla młodych ludzi symbolem wolności i buntu przeciw konserwatywnym wartościom starszego pokolenia. Dzisiaj jest już niemalże regułą, że wykonawcy, który marzą o międzynarodowej karierze, muszą wykonywać swoje utwory $w$ języku angielskim. Podobna sytuacja panuje w kinematografii. Wg danych z $1995 \mathrm{r}$. w latach 90-tych USA kontrolowały ok. $85 \%$ światowego rynku filmowego ${ }^{34}$.

Angielski jest bez wątpienia lingua franca współczesnego świata. W przeszłości wielokrotnie podejmowano próby utworzenia języka wszechludzkiego, który pomógłby pokonać trudności związane z komunikowaniem się różnych narodowości. Wydawałoby się więc, że wreszcie spełniły się marzenia ludzkości o uniwersalnym języku. Dominacja języka angielskiego budzi jednak niepokój wśród wielu językoznawców i użytkowników języków narodowych. Przed taką wszechpotęgą języka angielskiego przestrzegał Edward Sapir już w 1933 roku, a więc w okresie, gdy angielski nie miał jeszcze pewnej pozycji jako najważniejszy język międzynarodowy: „Angielski przyjęty jako język międzynarodowy nie byłby bardziej bezpieczny niż francuski przyjęty jako jedyny język dyplomacji $i$ łacina jako międzynarodowy język nauki. (...) Jest niewatpliwie prawdq, że dla wielu przyszłych pokoleń język międzynarodowy musi pozostać językiem pomocniczym, nie może skutecznie rywalizować z licznymi językami

\footnotetext{
33 D. Crystal, op. cit., s. 87-89.

34 Por. D. Crystal, op. cit., s. 91-95
} 
etnicznymi, zarazem jednak musi mieć charakter pełnowartościowego narzędzia ekspresji, zdolnego do wypetnienia wszelkich zadań, jakie wolno wiqzać z językiem, a przy tym zabezpieczajqcego przed wszelkq interpretacja pomawiajaca go o lokalizm czy stronniczość narodowościowq"35. Idea łatwego porozumiewania się przy pomocy języka sztucznego zrodziła się już w starożytności. W 1905 r. Adam Zakrzewski podał wykaz ponad 200 języków sztucznych, w których ich twórcy upatrywali uniwersalnego medium międzynarodowej komunikacji językowej. Największą popularność w roli pomocniczego języka międzynarodowego zdobyło esperanto Ludwika Zamenhofa, które obecnie praktycznie zostało zapomniane ${ }^{36}$, choć jako język neutralny mogłoby ono zagwarantować „pokojowe” współistnienie innych języków. Jest wiele przyczyn, dla których esperanto nie rozprzestrzeniło się na świecie. Przede wszystkim wskazuje się na niedoskonałości konstrukcyjne systemu, a także na fakt, że esperanto jako język sztuczny nie podlega regułom permanentnego rozwoju, które cechują języki naturalne i umożliwiają im samoczynne dopasowanie się do potrzeb zmieniającej się rzeczywistości. O ostatecznym odrzuceniu esperanto jako języka międzynarodowego przesądziła ONZ, która przed około 30 laty, częściowo z przyczyn politycznych, nie zaakceptowała wniosku o nadanie mu statusu języka światowego ${ }^{37}$.

Jacek Perlin we wstępie ${ }^{38}$ do polskiego przekładu książki Tortosy Polityka językowa a języki mniejszości: od Wieży Babel do Daru Języków stwierdza, że we współczesnym świecie nie jest bez znaczenia, jaki język jest językiem ojczystym użytkownika, bowiem jest on podstawą dostępu do dóbr kulturalnych. Amerykanie czy Anglicy znajdują się w sytuacji uprzywilejowanej w stosunku do członków innych wspólnot językowych, ponieważ nie mają potrzeby opanowywania języka krajów silniejszych. Sam Tortosa upatruje w wymaganiach znajomości języka angielskiego $w$ wielu ofertach pracy ukazujących się w Hiszpanii

\footnotetext{
35 Cytat za: E. Sapir, Zagadnienia międzynarodowego języka pomocniczego, w: tegoż, Kultura, język, osobowość, Warszawa 1978, s. 115.

36 Por. T. Wiśniewski, Ludwik Zamenhof, Białystok 1987, s. 17.

37 Por. J. Horvath, Die Lingua Franca des Netzes, w: Telepolis. Magazin der Netzkultur, Hannover 1997, s. 6, www.heise.de

38 Por. J. Perlin, Wstęp, (w:) J. M. Tortosa, op. cit., s. 13.
} 
symptomu funkcjonowania imperium poprzez rynek, którego rezultatem jest imperialna penetracja, kształtująca świat i „porządek” międzynarodowy ${ }^{39}$. Według niego, kultura, język i nauka mogą stać się najbardziej przydatnymi instrumentami służącymi utrzymaniu imperium. Na korzyść języka imperium działają dwa fakty: pierwszy jest typu technologicznego, drugi ma raczej charakter społeczny. Międzynarodowy porządek językowy jest hierarchią feudalną, odzwierciedlającą i uwieńczającą hierarchię imperialną ${ }^{40}$. Podobny punkt widzenia reprezentuje Robert Phillipson, który dominację języka angielskiego nazywa imperializmem językowym zapoczątkowanym przez Imperium Brytyjskie i skutecznie rozwijanym przez państwa anglojęzyczne $w$ postaci pomocy udzielanej krajom trzeciego świata $\mathrm{w}$ rozwoju edukacyjnym, a także $w$ instytucjonalnym promowaniu kultury poprzez naukę języka prowadzoną przez takie organizacje jak British Council (Wielka Brytania) czy State Department (USA) ${ }^{41}$. W roboczej definicji imperializmu języka angielskiego Phillipson stwierdza, że dominacja ta jest popierana i utrzymywana poprzez formy organizacyjne oraz ciągłą odbudowę dysproporcji strukturalnych i kulturalnych pomiędzy językiem angielskim i innymi językami ${ }^{42}$. Dla przykładu, na początku XX w. Amerykanie wprowadzili w szkolnictwie na Filipinach język angielski jako podstawowy język nauczania. „Poprzez amerykańskie teksty podręcznikowe mieszkańcy Filipin zaczęli uczyć się nie tylko nowego języka, lecz także nowego sposobu życia. Mistrzowskie władanie językiem angielskim stało się oznakq człowieka wykształconego... Kolonialne relacje między Amerykanami i mieszkańcami Filipin unaoczniaja, że język jest potęq. Poprzez podstępne narzucenie angielskiego kraj uzależnił się od zapożyczonego języka, który przyniósł ze sobq dominujacq ideologię i polityczno-ekonomiczne korzyści dla USA"43. Dominacja języka angielskiego, nazywana przez Phillipsona imperializmem językowym, jest raczej skutkiem globlizacji, która objęła gospodarkę i ekonomikę znacznie wcześniej niż inne dziedziny, zapewniając nie tylko

\footnotetext{
39 Por. J. M. Tortosa, op. cit., s. 78.

40 Tamże, s. 82-86.

41 Por. R. Phillipson, Linguistic imperialism, Oxford 1996, s. 1.

42 Tamże, s. 47.

43 Cytat za: R. Phillipson, op. cit., s. 153-54.
} 
samym Stanom Zjednoczonym, ale i językowi angielskiemu uprzywilejowaną pozycję. W ostatnich 30 latach nauczanie języka angielskiego stało się jedną $\mathrm{z}$ najbardziej dynamicznie rozwijających się gałęzi biznesu. W latach 1995-96 pod administracją organizacji British Council, która w 1996 r. miała swoje przedstawicielstwa 109 krajach świata, ponad 400 tys. osób złożyło egzamin potwierdzający znajomość języka angielskiego. Szczególny przyrost zainteresowania nauką języka angielskiego obserwuje się w Europie Środkowej. W byłych republikach ZSSR języka angielskiego uczy się około $10 \%$ populacji, co stanowi $50 \mathrm{mln}$ osób ${ }^{44}$.

Wiek XX i początek wieku XXI są triumfem języka angielskiego. W świecie, który stał się "globalną wioską", komunikacja językowa z przedstawicielami innych narodowości, którzy są daleko, a zarazem tak blisko, staje się potrzebą codzienną. Uniwersalne medium, jakim jest język angielski, ułatwia funkcjonowanie w wielu sferach życia, ale jako język dominujący angielski wywiera wpływ na inne języki, czego symptomem jest degradacja ich pozycji, a także przejmowanie przez nie potrzebnych, ale i zbytecznych zapożyczeń językowych.

44 Por. D. Crystal, op. cit., s. 103. 